\title{
Extreme temperature trends in the equatorial region of Brazil: Case study of the State of Ceará ${ }^{1}$
}

\author{
Tendência das temperaturas extremas em região equatorial brasileira: estudo de caso \\ do Estado do Ceará
}

\author{
Eunice Maia de Andrade ${ }^{2}$, Bernardo Barbosa da Silva ${ }^{3}$, Meilla Marielle Araújo Rodrigues ${ }^{4}$, Marcos Amauri \\ Bezerra Mendonça ${ }^{5}$ e Luiz Carlos Guerreiro Chaves ${ }^{5 *}$
}

\begin{abstract}
Despite uncertainties as to the real causes, there is a large amount of evidence of climatic change on Earth. With the objective of investigating changes in extreme air temperatures, as well as the local effects of these changes, eight data sets, collected throughout the State of Ceará in Brazil, were analyzed. Four series of data were obtained from the semi-arid region, three from the coastal zone, and one from a mountainous region. To quantify the changes that occurred during the study period, variations in maximum and minimum temperatures were calculated in relation to the mean of each data series. The annual rates of temperature increase were estimated from the angular coefficients of the best-fit lines. The results showed that although there are differences in trends between stations, there was a systematic increase in the maximum and minimum temperature in the nineties, which was especially evident in the following decade. The highest rates of increase were recorded for the minimum temperatures (from 9.0 to $8.3{ }^{\circ} \mathrm{C}$ per century) for the stations at Guaramiranga and Crateús respectively. These data provide evidence for a greater retention of energy in the form of sensible heat during the night, possibly due to a more difficult energy exchange between the surface and the atmosphere.
\end{abstract}

Key words - Climatic changes. Global warming. Air temperature.

\begin{abstract}
Resumo - Apesar das incertezas sobre as verdadeiras causas, há uma grande quantidade de evidências de mudanças climáticas na Terra. Com o objetivo de investigar as mudanças em temperaturas extremas do ar, bem como os efeitos locais das mudanças, oito conjuntos de dados coletados ao longo do Estado do Ceará, Brasil, foram analisados. Quatro série de dados foram obtidas a partir da região semi-árida, três da zona costeira e uma de uma região montanhosa. Para quantificar as mudanças que ocorreram durante o período do estudo, as variações nas temperaturas máximas e mínimas foram calculadas em relação à média de cada série. As taxas anuais de aumento de temperatura foram estimadas pelos coeficientes angulares das linhas de melhor ajuste. Os resultados mostraram que, embora haja diferenças nas tendências entre as estações, ocorreu um aumento sistemático da temperatura máxima e mínima, que foi especialmente evidente na década seguinte, dos anos 90 . As maiores taxas de crescimento foram registradas para as temperaturas mínimas (de 9,0 a $8,3{ }^{\circ} \mathrm{C}$ por século) para as estações de Guaramiranga e Crateús, respectivamente. Estes dados fornecem evidências para a maior retenção de energia na forma de calor sensível durante a noite possivelmente devido a uma troca de energia mais difícil, entre a superfície e a atmosfera.
\end{abstract}

Palavras-chave - Mudanças climáticas. Aquecimento global. Temperatura atmosférica.

\footnotetext{
*Autor para correspondência

${ }^{1}$ Recebido para publicação em 15/03/2011; aprovado 11/10/2011

Pesquisa financiada pela Universidade Federal do Ceará

${ }^{2}$ Departamento de Engenharia Agrícola, CCA/UFC, Fortaleza-CE, Brasil, eandrade@ufc.br

${ }^{3}$ Departamento de Ciências Atmosféricas da Universidade Federal de Campina Grande-PB, Brasil, bernardo@ dca.ufcg.edu.br

${ }^{4}$ Graduanda em Agronomia, CCA/UFC, Fortaleza-CE, Brasil, meillamarielle@ hotmail.com

${ }^{5}$ Programa de Pós-Graduação em Engenharia Agrícola, CCA/UFC, Fortaleza-CE, Brasil, amauriufc@gmail.com, luizcarlosguerreiro@gmail.com
} 


\section{Introduction}

Since the start of the second half of the $20^{\text {th }}$ century, meteorological observations have been registering systematic increases in the air temperatures, both at the global and regional scales (SILVA, 2004). Research studies conducted in different parts of the world (LEBASSI et al., 2009; LINKOSALO et al., 2009; WALTERS et al., 2007) have identified that the increases in the minimum air temperatures are more significant than increases in the maximum air temperatures. The increases of air temperature occur in an asymmetric form, representing the effects of different global and regional agents (PITMAN; PERKINS, 2009) on the air temperature changes. The asymmetries of these changes have had significant impacts in many regions of the globe, while in other places no significant changes have been observed (BONSAL et al., 2001; PRIETO et al., 2004).

Anthropogenic action is being considered as the main reason for these changes (IPCC, 2007), both at the global (BALLESTER et al., 2010; VOSE et al., 2005) and regional (BROHAN et al., 2006; LOBELL; BONFILS, 2008) scales. The best example of an anthropogenic effect on the local air temperature is the urban heat island effect, which has been investigated in different cities (KOLOKOTRONI; GIRIDHARAN, 2008; LOPES et al., 2008; PEREIRA; MORAIS, 2007). Unfortunately, many uncertainties still exist regarding the real cause responsible for generating these climatic changes that have been registered in the last two decades (SPENCER, 2010).

The projections of these changes indicate that the increase in air temperatures will promote climate changes that could affect the planet significantly, especially in regions of extreme temperatures, with a greater impact on the tropical regions and the less developed countries (IPCC, 2007). These changes in temperatures will promote alterations in the distribution of precipitation (MARENGO et al., 2009) and on the water availability (MARENGO; VALVERDE, 2007), which will have serious impacts for natural systems and human life (HOMAR et al., 2010; PETERSON, 2003).

As an example, the document "Climate Change 2007: The Physical Science Basis" (IPCC, 2007) suggested that the semiarid regions of the globe could undergo desertification, thereby becoming unsuitable for human life. Researchers such as Marengo (2008) have commented that maximum air temperatures in the northeast region of Brazil have increased between 1.5 and $2.0^{\circ} \mathrm{C}$ in the last 40 years. Just like all the tropical arid and semiarid regions of the globe, the Brazilian northeast naturally presents a high potential for evaporation due to the high solar energy availability. This natural condition, associated with the increase in sensible heat (air temperature) due to global warming, will result in a higher rate of lake evaporation as well as a higher demand for water by the vegetation (increase in the evapotranspiration rates). In this scenario of extremely limited water resources, the sustainability of the regional development could be compromised unless, due to global warming, the depth of rainfall also increases. Based on these questions, this study focused on the investigation of the tendency of extreme air temperature changes (maximums and minimums) in three different climate areas of Ceará State, Brazil.

\section{Material and methods}

\section{Region description}

The studied area corresponds to the Ceará State (FIG. 1) in the semiarid region of the northeastern part of Brazil, which is characterized by a unimodal rainfall distribution with a high spatial and temporal variability. It exhibits an average potential evaporation rate of 2,527.6 mm year-1 with an insolation of 2,776.4 hours year $^{-1}$ and an average global radiation of $23 \mathrm{MJ} \mathrm{m}^{-2}$ day $^{-1}$.

The dominant climate of the region, which comprises $80 \%$ of the State's area, according to Koppen's classification is semiarid - BSw'h'; the remaining $20 \%$ is almost entirely classified as sub-humid climate (Aw') (coastal region). There are also small mountain regions where the climate is classified as Am (mountain climate) (TAB. 1).

Among the meteorological stations considered in this study, one is located in the city of Fortaleza, which has a population of 2.4 million people, and the other 7 stations are distributed in urban centers with populations of less than 40 thousand people. Although it is a metropolis, the city of Fortaleza was included in the study due to the fact that the station is situated in the Campus of the Universidade Federal do Ceará (area of 100 ha) in a place that has a great vegetated area without drastic alterations in its vicinities.

\section{Data set}

In order to identify changes in extreme air temperature monthly datasets (1961/2008) including absolute maximum and minimum temperatures measured two meters above the ground in eight meteorological stations throughout the Ceará State were employed. The data was provided by the $3^{\text {rd }}$ INMET district and by the Universidade Federal do Ceará. The first part of the study was to investigate whether there were any missing data in the monthly time series. Any missing data in the data were filled by the value of the mode of the respective month. To investigate whether the extreme temperatures registered in the meteorological stations in the Ceará State are undergoing successive increases, as well as to quantify these increases, the annual increment of the maximum and minimum temperatures was determined in relation to the 
Figure 1 - Studied area location

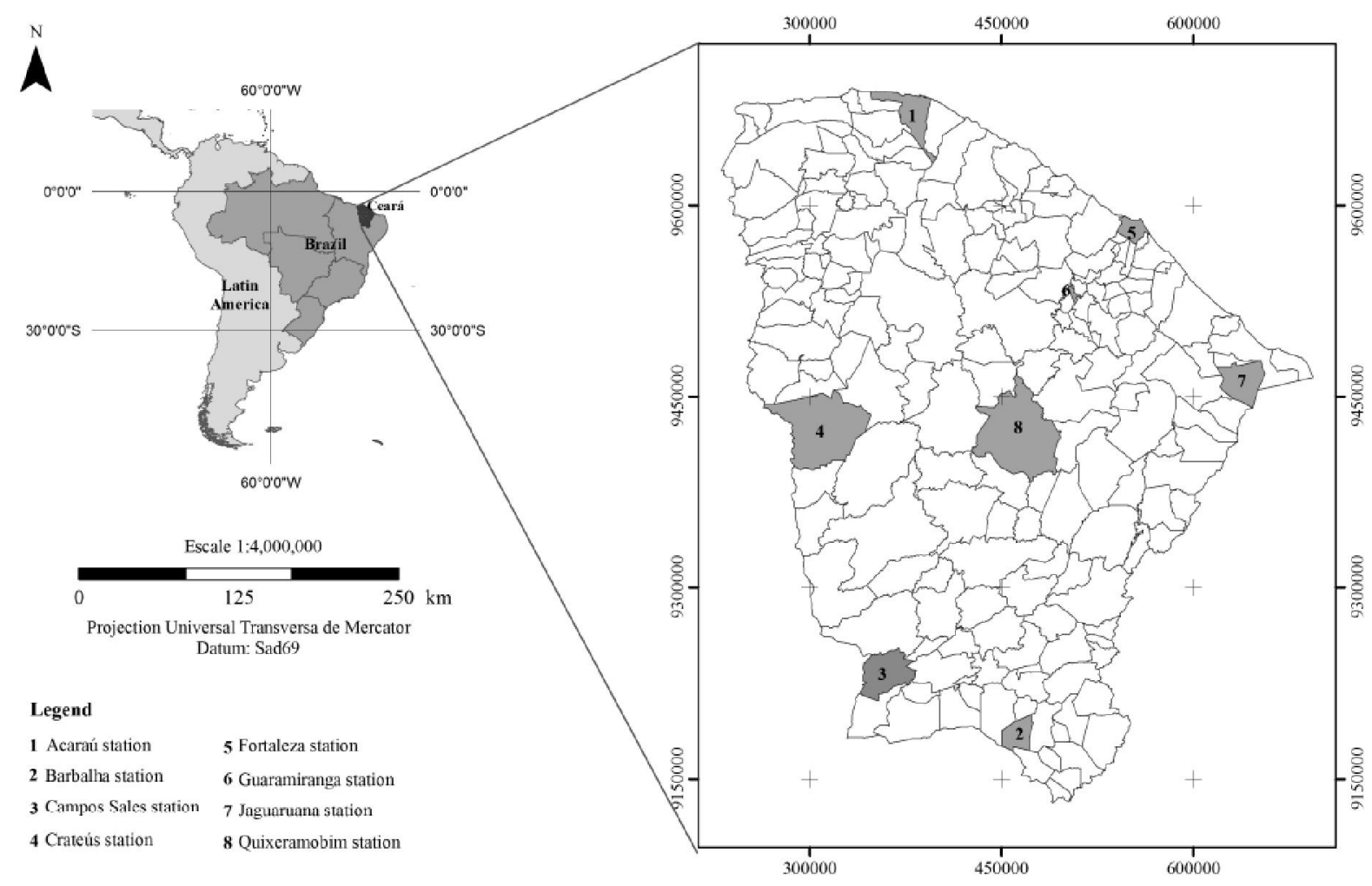

Table 1 - Identification of the meteorological stations

\begin{tabular}{llllcc}
\hline \multicolumn{1}{c}{ Stations } & Regions & Latitude & Longitude & Altitude $(\mathrm{m})$ & Climate \\
\hline Cratéus & Arid land & $05^{\circ} 10^{\prime} \mathrm{S}$ & $40^{\circ} 40^{\prime} \mathrm{W}$ & 297.00 & BSw'h' \\
Quixeramobim & Arid land & $05^{\circ} 10^{\prime} \mathrm{S}$ & $39^{\circ} 17^{\prime} \mathrm{W}$ & 179.50 & BSw'h' \\
Barbalha & Arid land & $07^{\circ} 19^{\prime} \mathrm{S}$ & $39^{\circ} 18^{\prime} \mathrm{W}$ & 409.00 & BSw'h' \\
Campos Sales & Arid land & $07^{\circ} 00^{\prime} \mathrm{S}$ & $40^{\circ} 23^{\prime} \mathrm{W}$ & 583.50 & $\mathrm{BSw}{ }^{\prime} \mathrm{h}^{\prime}$ \\
Acaraú & Coastal & $02^{\circ} 53^{\prime} \mathrm{S}$ & $40^{\circ} 08^{\prime} \mathrm{W}$ & 16.50 & $\mathrm{Aw}$ \\
Fortaleza & Coastal & $03^{\circ} 45^{\prime} \mathrm{S}$ & $38^{\circ} 33^{\prime} \mathrm{W}$ & 19.53 & $\mathrm{Aw}$ \\
Jaguaruana & Coastal & $04^{\circ} 47^{\prime} \mathrm{S}$ & $37^{\circ} 46^{\prime} \mathrm{W}$ & 11.70 & $\mathrm{Aw}$ \\
Guaramiranga & Mountain & $04^{\circ} 17^{\prime} \mathrm{S}$ & $39^{\circ} 00^{\prime} \mathrm{W}$ & 871.00 & $\mathrm{Am}$ \\
\hline
\end{tabular}

median in each series, as well as to the five-year moving average. To investigate the tendency of the extreme values and the year when they occurred, the five highest values $\left(95^{\text {th }}\right.$ percentile) and the five lowest values $\left(5^{\text {th }}\right.$ percentile) were considered for the three hottest months and the three coldest months recorded at each station. To quantify the increase in the rate of the extreme temperatures, of the best fit lines for the annual data were adjusted and parameter coefficients were tested at a 5\% significant level.

\section{Results and discussion}

Table 2 shows some descriptive statistics for the maximum and minimum air temperature in the eight meteorological stations. Table 2 reflects a low variability (standard deviation and coefficient of variation) for all stations. The highest registered variability was for station Barbalha with coefficient of variation values above $10 \%$, followed by Cratéus, Quixeramobim and Campos Sales stations, all located in the semiarid region. 
Table 2 - Maximum, minimum, mean, SD (standard deviation) and CV (coefficient of variation) for the air temperature monthly datasets $(1961 / 2008)$

\begin{tabular}{lcccccccccc}
\hline \multirow{2}{*}{ Stations } & \multicolumn{4}{c}{ Maximum Air Temperature } & \multicolumn{4}{c}{ Minimum Air Temperature } \\
\cline { 2 - 12 } & Max & Min & Mean & SD & CV & Max & Min & Mean & SD & CV \\
\hline Cratéus & 39.80 & 30.80 & 35.35 & 1.93 & 5.46 & 23.50 & 12.00 & 19.63 & 1.94 & 9.90 \\
Quixeramobim & 39.60 & 29.90 & 34.81 & 1.95 & 5.59 & 24.00 & 13.70 & 20.80 & 1.52 & 7.31 \\
Barbalha & 39.90 & 29.80 & 34.08 & 2.22 & 6.50 & 22.00 & 10.40 & 17.81 & 2.04 & 11.48 \\
Campos Sales & 39.90 & 28.50 & 33.37 & 1.99 & 5.97 & 21.40 & 10.80 & 17.73 & 1.78 & 10.04 \\
Acaraú & 37.10 & 30.20 & 33.51 & 1.19 & 3.57 & 23.00 & 15.10 & 20.71 & 1.22 & 5.55 \\
Fortaleza & 34.20 & 23.60 & 31.77 & 0.85 & 2.67 & 26.60 & 16.60 & 22.03 & 1.22 & 5.91 \\
Jaguaruana & 41.00 & 30.80 & 35.25 & 1.54 & 4.37 & 23.80 & 14.50 & 20.80 & 1.47 & 7.07 \\
Guaramiranga & 35.60 & 23.40 & 27.15 & 1.74 & 6.41 & 19.20 & 10.00 & 16.61 & 1.34 & 8.07 \\
\hline
\end{tabular}

Fortaleza station showed the lowest variability among studied stations, and that fact can be explained by the place where the station is sited (Campus of the Universidade Federal do Ceará). In the Campus, there are a great vegetated area (>100 ha) without drastic alterations.

\section{Maximum air temperatures}

The registered temperatures in the eight studied stations clearly indicate an increase in the maximum temperatures, regardless of the geographical position (coastal, semiarid land or mountain). After the year 1996, the maximum temperatures were all above the median dataset temperatures for almost stations, and the increments were positively increasing (FIG. 2). Although the city of Fortaleza has a population of 2.4 million that is 60 times larger than the populations of the other urban centers, the temperature trends is similar to the other stations.

The urban heat island effect, defended by Peterson (2003), with respect to the temperatures in large urban centers (populations greater than 100,000), was not observed at the station in the city of Fortaleza city. This result can be explained by the location of the aforementioned station, which is installed at the Campus of the Universidade Federal do Ceará, where there is a considerable amount of vegetated area and an absence of nearby buildings. The absence of the urban island effect at the CCA/UFC meteorological station was also identified by Lopes et al. (2008), when a comparative study between the temperatures of two meteorological stations in two different places of the city was conducted.

In the studied period, the extremes in the annual averages of the maximums air temperatures were registered in 1998 and in 2007 (FIG. 2), with the four highest increments occurring during the last ten years. The highest increases occurred in the Crateús, Quixeramobim and Campos Sales stations located in the BSw'h' climate region. The lowest increases were observed in the city of Guaramiranga, which is located in a region with a climate classified as Am. As for the stations located in Fortaleza, Acaraú and Jaguaruana, which are in the coastal region (sub-humid climate), the station in Acaraú registered the largest increases in temperature during the last decade.

The tendency towards an increase in temperature, as well as the smaller variability of the increments, can be observed in the five-year moving average. A systematic increase in temperature was observed in all eight studied stations, representing a tendency of the climatic changes in the region. In studies regarding the maximum and minimum temperatures in southern Brazil for the period of 1961 to 2002, Marengo and Valverde (2007) also identified tendencies for the increases of these temperatures, illustrating a continued heating of the south region of Brazil.

The Acaraú station (coastal region) exhibited the highest tendency for a systematic increase in the annual average of the maximum temperatures (FIG. 2), while the highest variability for the tendency of increase was verified for the stations in Campos Sales (semiarid climate) and Guaramiranga (mountain climate). This fact express that temperature changes are independent of the climatic classification. Also, it was observed that all stations exhibited a tendency toward an increase in temperature after the decade of the 90s. This is in accordance with the IPCC (2007), which commented that the increase of $0.65^{\circ} \mathrm{C}$ in the average temperature of the globe was more evident after the start of that decade.

\section{Minimum air temperatures}

Except for the temperatures registered in Fortaleza, the highest values for the minimum temperatures occurred in 1998 (FIG. 3), which characterizes that year as the 
Figure 2 - Percentage of increase in the maximum temperatures in relation to the average and the five-year moving average for the temperatures of the studied stations

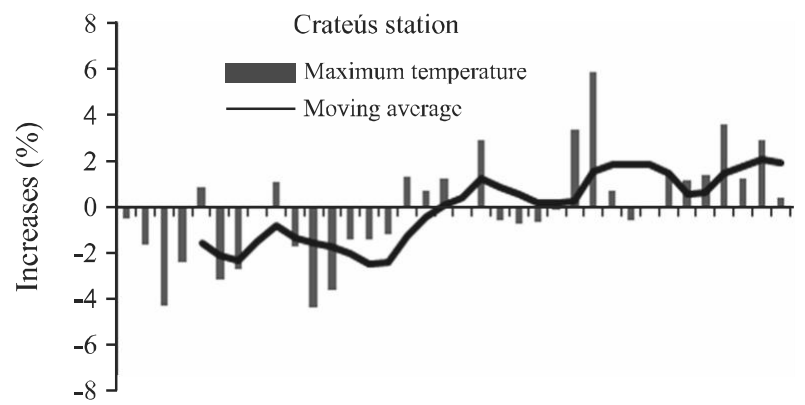

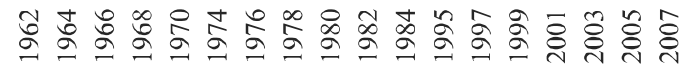

Year

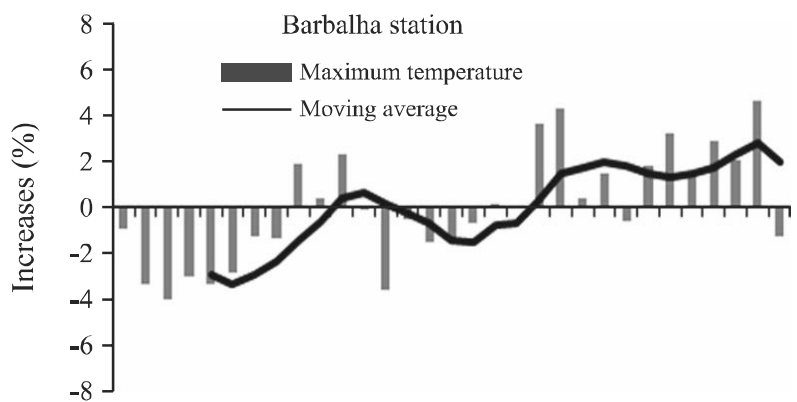

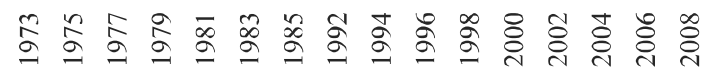
Year

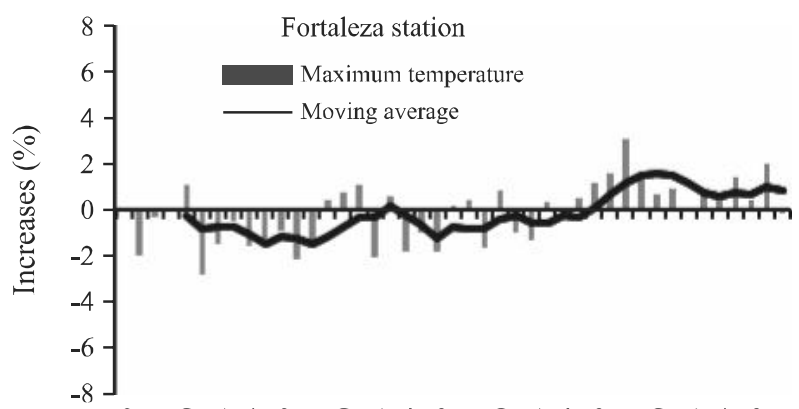

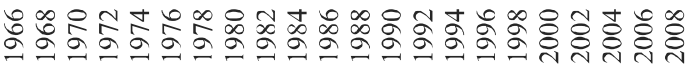

Year

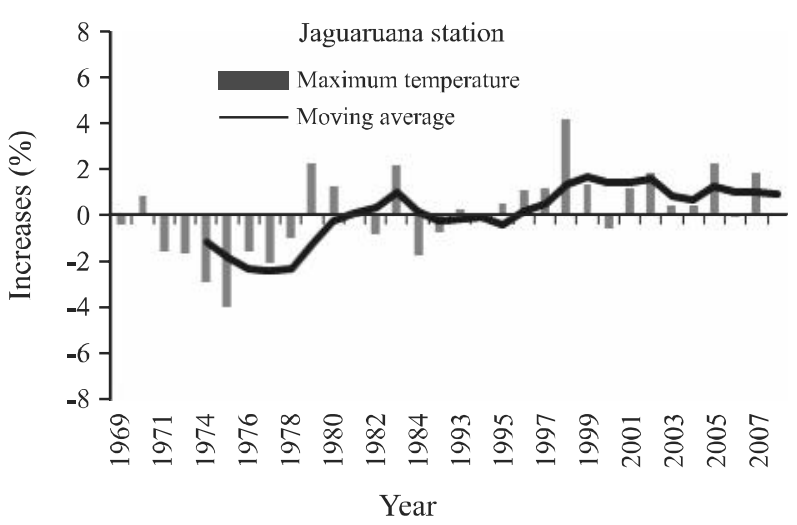

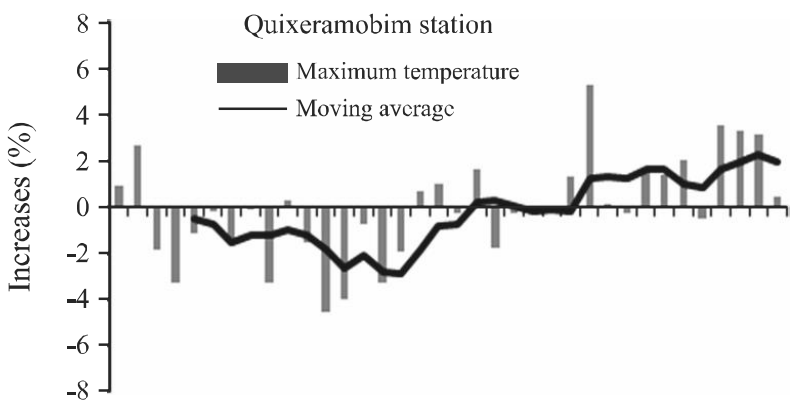

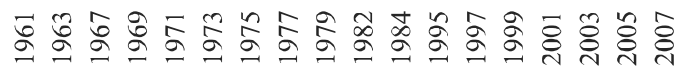
Year

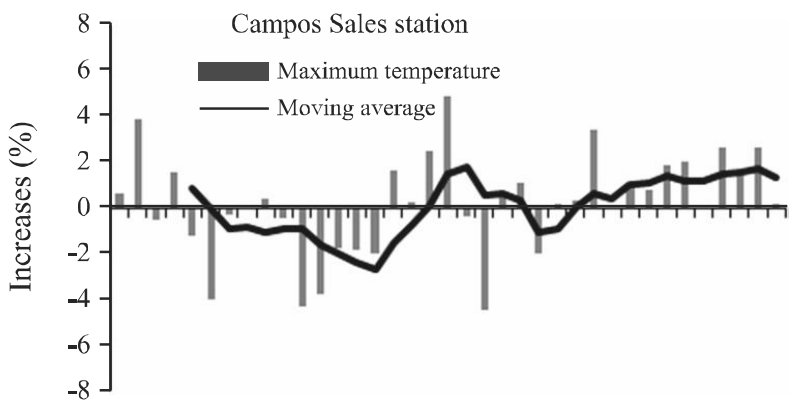

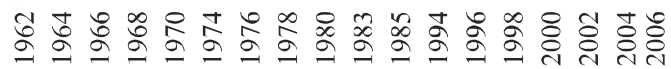

Year

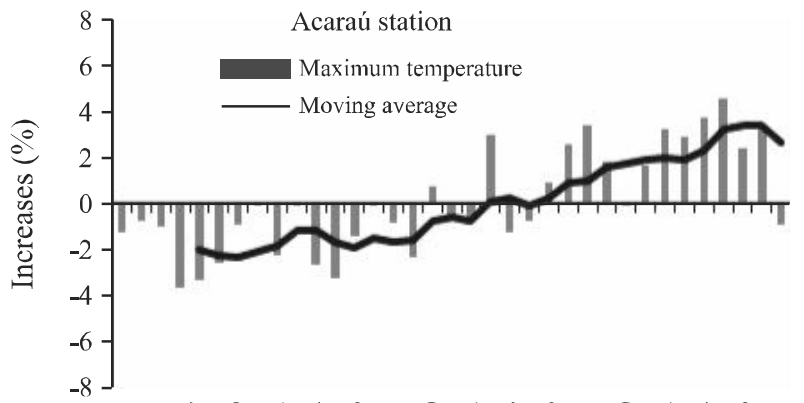

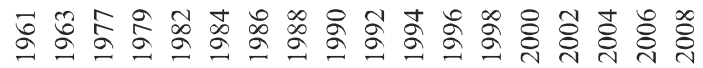
Year

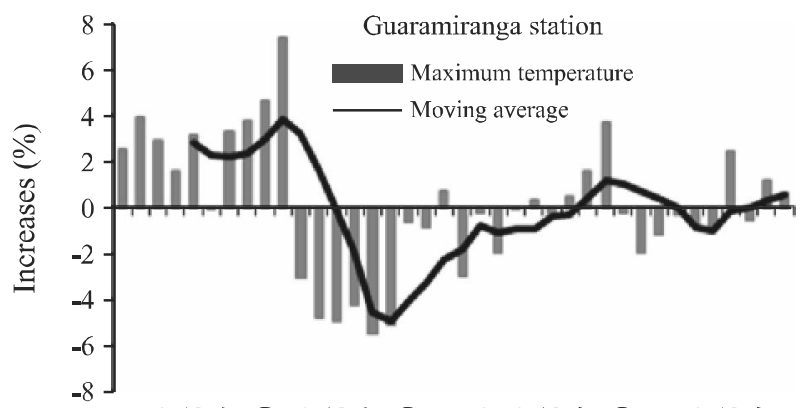

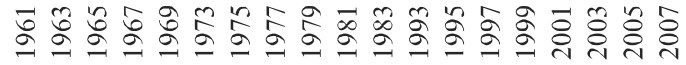
Year 
hottest year during the studied period. The same situation was observed for the maximum temperatures. Just as it did for the absolute maximums, the 90s decade exhibited absolute minimums above the normal average, and this tendency was confirmed in the 2000-2010 decade.

Among the four stations that represent the semiarid climate (Crateús, Quixeramobim, Campos Sales and Barbalha), the highest variations were observed for the station at Barbalha. Although the temperatures registered in the four stations may exhibit the same tendency, specific behaviors to each of them were observed. For example, there is a higher similarity among the registered temperatures in Quixeramobim and Campos Sales stations. The smallest variations in the annual average temperature $(<5 \%)$ were identified in the station of Jaguaruana, while the station of Guaramiranga exhibited the most number of years ( 22 in total) with annual averages above the median of dataset. In the last two decades, many researchers (LEBASSI et al., 2009; LOBELL; BONFILS, 2008; MARENGO; VALVERDE, 2007) have studied and discussed the influence of land use in the variations of air temperature.

With the exception of temperatures registered in the Fortaleza city, it was verified that after the year 1995, the annual minimum temperature averages were all above the average. This fact confirms what has been observed by other researchers in different parts of the globe (FERRON et al., 2001; HOMAR et al., 2010; KOLOKOTRONI; GIRIDHARAN, 2008).

The tendency toward systematic increases in the minimum temperatures can be confirmed by the five-year moving average (FIG. 3). In the last two decades, the moving average, with the exception of the minimum temperatures of Fortaleza, has been greater than the normal average for the minimum temperatures. The minimum temperatures of the Fortaleza station, although the population of the city is greater than 2.4 million people, do not point towards the urban heat island effect because there is no tendency towards a systematic increase in the minimum temperatures.

According to researchers such as Lebassi et al. (2009), Pereira and Morais (2007) and Walters et al. (2007), the increase in the minimum temperatures of the great urban centers that generate the urban heat island effect is a result of the greater retention of heat during the night due to a higher difficulty in the exchange of this heat. It is believed that this effect still does not exist at the Fortaleza station due to its location, the Universidade Federal do Ceará Campus, where there is an organized occupation of the space near the station.

\section{Air temperature change}

The best fit lines for each station (FIG. 4) reveal a tendency towards an increase in the maximum and minimum temperatures at rates varying from 0.0005 to $0.0568{ }^{\circ} \mathrm{C}$ year $^{-1}$ for the maximums and from 0.018 to $0.0903{ }^{\circ} \mathrm{C}$ year ${ }^{-1}$ for the minimums. Except to maximum temperatures registered in the Fortaleza station, all temperature rates were statically significant at a level of $5 \%$.

Analysis of the three stations (Fortaleza, Acaraú, and Jaguaruana) representative of the coastal area revealed that the highest angular coefficients for maximum air temperatures were obtained for the station in Acaraú. The station in Fortaleza registered the lowest values $(0.0005$ and $0.0181{ }^{\circ} \mathrm{C}$ year $\left.^{-1}\right)$ of maximum and minimum temperatures rate increases, respectively. As for the stations located in the semiarid lands, the smallest rates of increase $(0.0163$ and $0.0604{ }^{\circ} \mathrm{C}$ year $^{-1}$ ) for the maximum and minimum air temperatures were registered in Campos Sales, respectively. The highest rates $\left(0.0813{ }^{\circ} \mathrm{C}\right.$ year $\left.{ }^{-1}\right)$ of maximum air temperature were obtained for the station in Crateús while the highest rates for minimum were identified in Barbalha station. These values confirm the high regional variability of the temperatures already observed in many different parts of the globe (HERTIG; JACOBEIT, 2008; HOMAR et al., 2010; LEBASSI et al., 2009).

In addition, it was found that the station representative of the mountain region (Guaramiranga) registered an increased rate in the absolute minimum temperature of $0.0903{ }^{\circ} \mathrm{C}$ year ${ }^{-1}$, which corresponds to an increase of $9.0^{\circ} \mathrm{C}$ per century. Data such as these reveal an increase in the minimum temperatures that is greater than the increase in the maximum temperatures. Similar results were also observed by other researchers (JUNG et al., 2002; LADOCHY et al., 2007; VOSE et al., 2005), showing that although there is a high regional variability in the increase of temperature, the same tendency of an increase is evident in different parts of the globe.

Another indicator of the detected increase in temperature is the fact that approximately $73 \%$ of the extreme observations (values greater than the $95^{\text {th }}$ percentile) of the maximum temperatures were observed in the last two decades, with $50 \%$ of these occurring in the period of 2000-2008 (TAB. 3). It is also observable that $85 \%$ of the lowest values in the maximum temperatures were registered in the 1960s and 70s, revealing a gradual increase in the diurnal temperatures. The variation of air temperature is attributable to the expression of energy in the form of sensible heat present in the air.

The increase in the diurnal temperatures may indicate a change in the land use, where surfaces of higher albedo or lower emissivity are replaced by others that despite its higher capacities for absorption and emission, replace the latent heat flux by sensible heat flux. Another use of land that can also promote increases in air temperature is the removal or reduction of the vegetated 
Figure 3 - Percentage of increase in the minimum temperatures in relation to the average and the five-year moving average of the temperatures in the studied stations
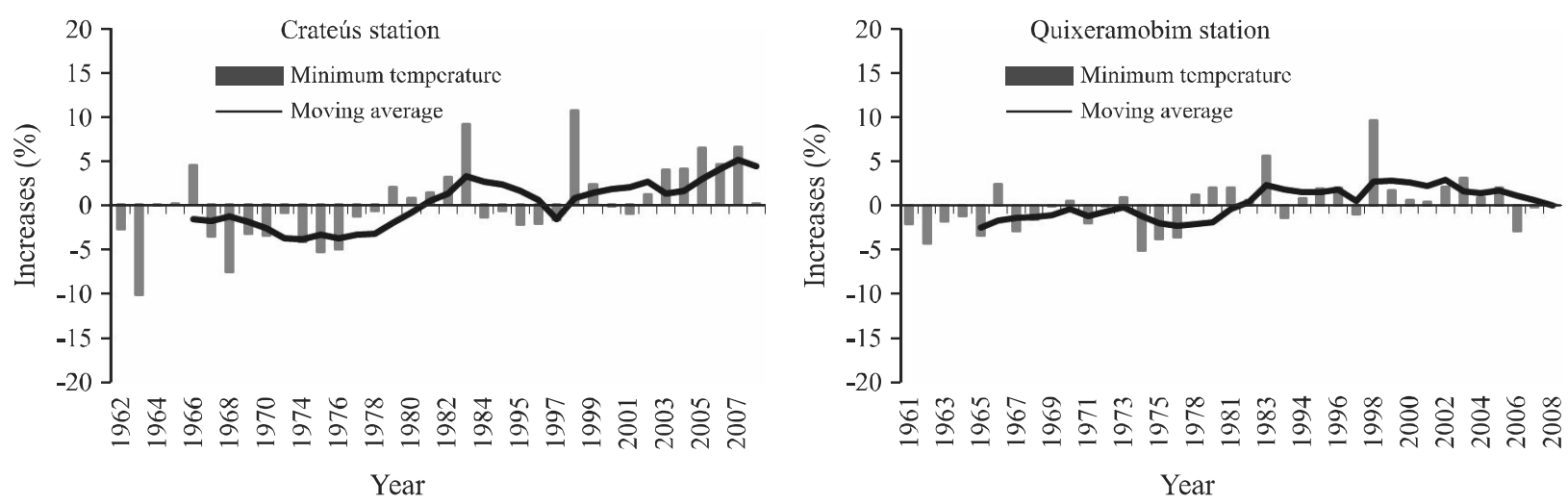

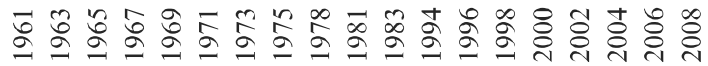

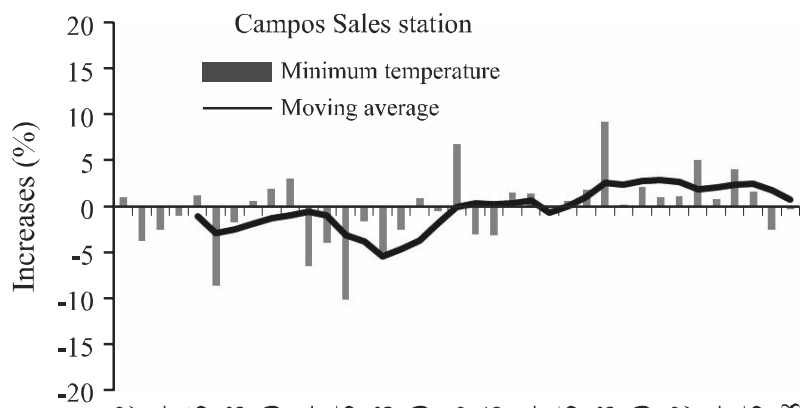

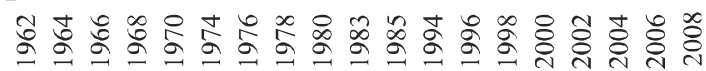

Year

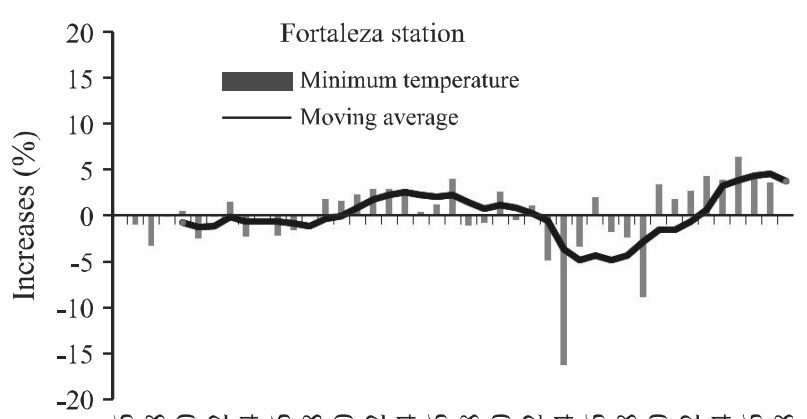

等

Year

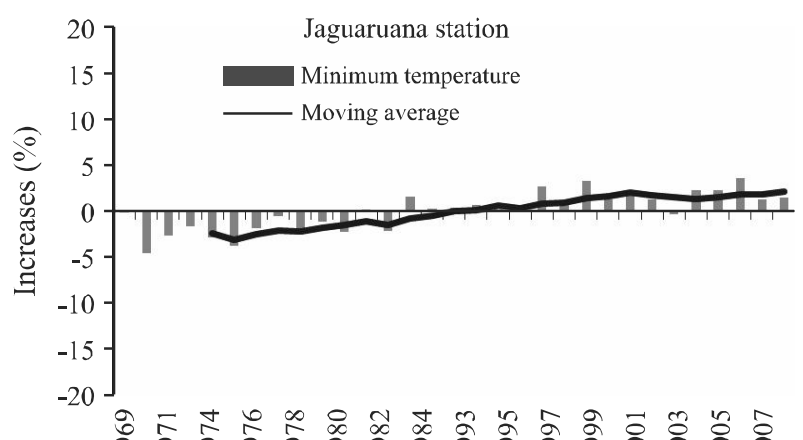

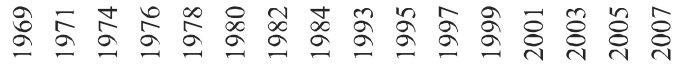
Year

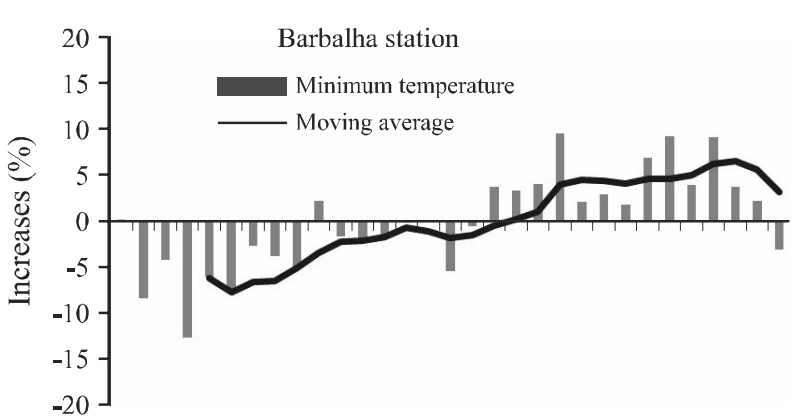

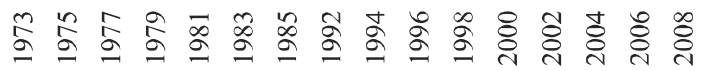
Year

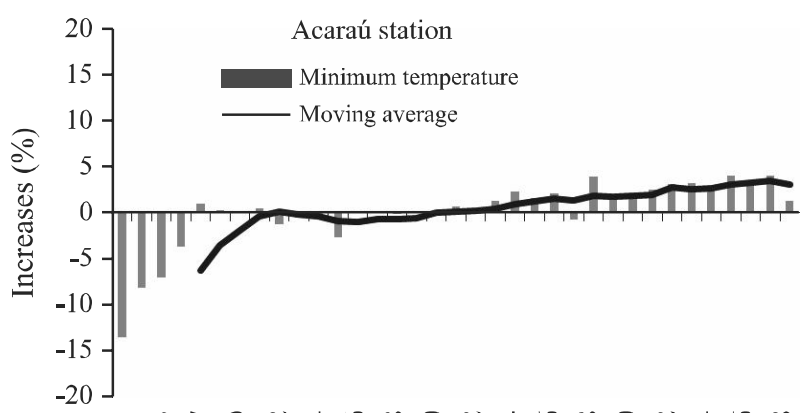

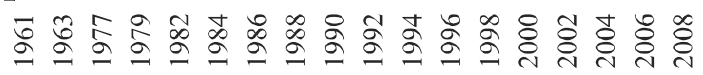

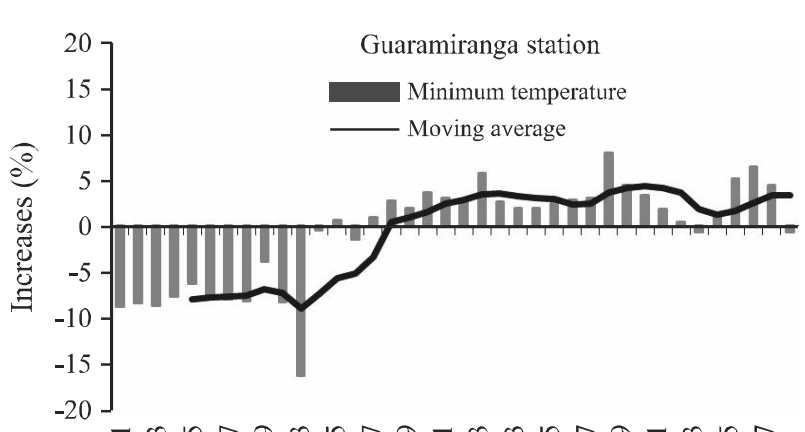

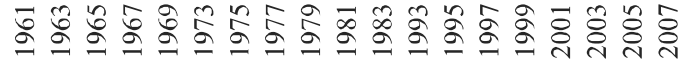
Year 
Figure 4 - Annual rates of maximum and minimum temperature increases for the investigated stations. $*$ - statically significant at level of $5 \%$
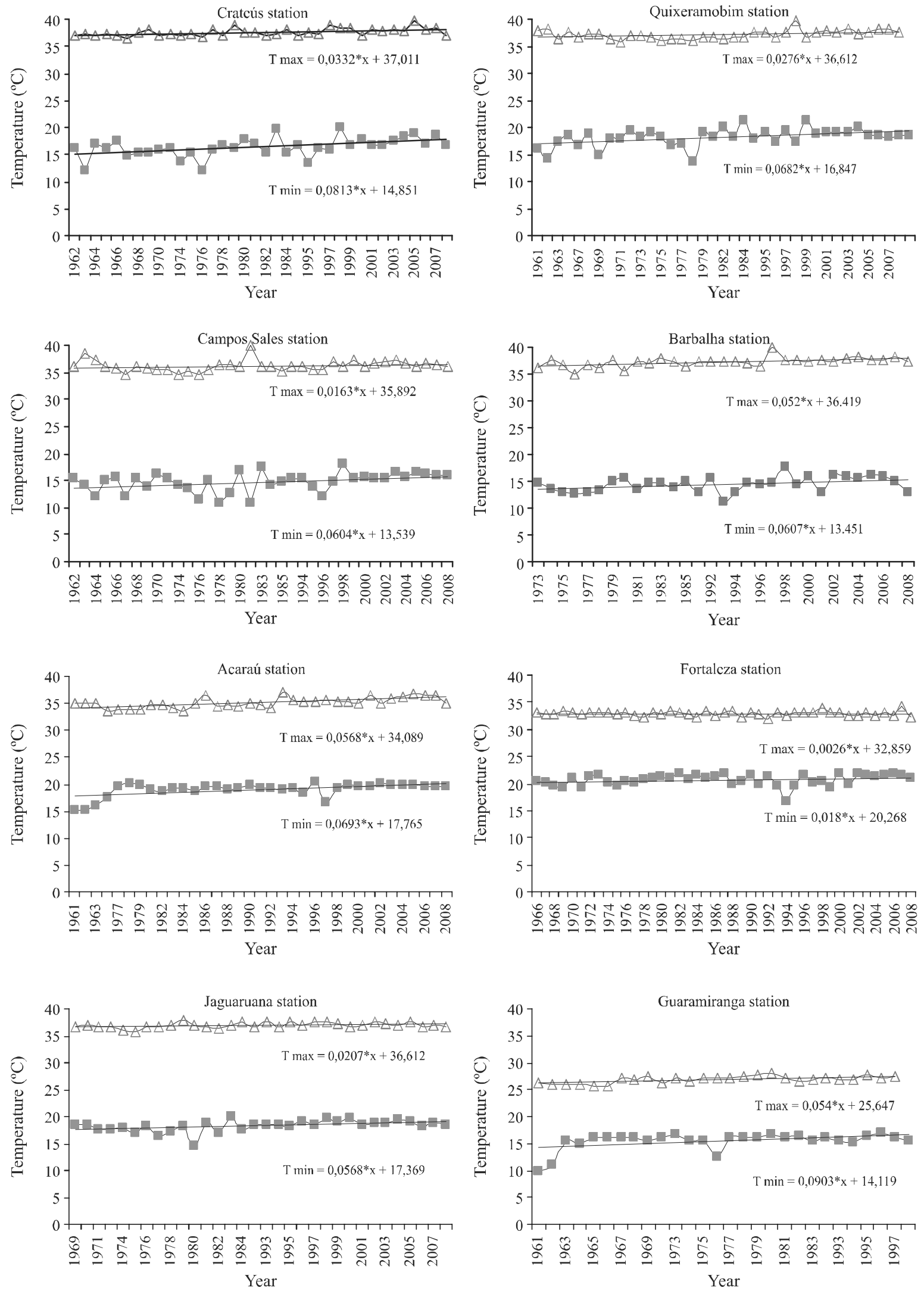
Table 3 - Register of the five biggest events present in the historical series of each investigated station with the respective year of occurrence

\begin{tabular}{|c|c|c|c|c|c|c|c|c|}
\hline \multirow{3}{*}{$\begin{array}{c}\text { Stations } \\
\text { Fortaleza }\end{array}$} & \multicolumn{4}{|c|}{ Maximum Temperatures } & \multicolumn{4}{|c|}{ Minimum Temperatures } \\
\hline & \multicolumn{2}{|c|}{$>$ Percentile $95 \%$} & \multicolumn{2}{|c|}{$<$ Percentile $5 \%$} & \multicolumn{2}{|c|}{$>$ Percentile $95 \%$} & \multicolumn{2}{|c|}{$<$ Percentile $5 \%$} \\
\hline & Year & Temp. & Year & Temp. & Year & Temp. & Year & Temp. \\
\hline 1 & 2007 & 34.2 & 1986 & 31.0 & 2005 & 23.9 & 1994 & 16.6 \\
\hline 2 & 1985 & 33.4 & 1976 & 31.0 & 2005 & 23.0 & 1994 & 16.8 \\
\hline 3 & 1976 & 33.2 & 1975 & 31.2 & 1983 & 22.8 & 1994 & 17.6 \\
\hline 4 & 2003 & 33.0 & 1971 & 31.2 & 2004 & 22.8 & 1971 & 19.3 \\
\hline 5 & 2004 & 33.0 & 1967 & 31.3 & 1983 & 22.7 & 1999 & 19.4 \\
\hline \multicolumn{9}{|l|}{ Acaraú } \\
\hline 1 & 2001 & 36.6 & 1976 & 32.3 & 1998 & 22.0 & 1963 & 17.7 \\
\hline 2 & 2007 & 36.0 & 1976 & 32.6 & 2002 & 21.2 & 1995 & 18.4 \\
\hline 3 & 2001 & 35.8 & 2008 & 32.7 & 1998 & 21.2 & 1985 & 18.6 \\
\hline 4 & 2004 & 35.7 & 2000 & 32.7 & 2007 & 21.2 & 1982 & 18.8 \\
\hline 5 & 2004 & 35.7 & 1991 & 32.7 & 1993 & 21.0 & 1988 & 18.9 \\
\hline \multicolumn{9}{|l|}{ Barbalha } \\
\hline 1 & 1997 & 38.5 & 1976 & 33.1 & 1998 & 19.6 & 1976 & 12.6 \\
\hline 2 & 2004 & 38.1 & 1976 & 33.3 & 2000 & 19.1 & 1976 & 12.7 \\
\hline 3 & 2007 & 38.1 & 1978 & 34.0 & 1997 & 18.7 & 2001 & 13.0 \\
\hline 4 & 2003 & 38.0 & 1980 & 34.3 & 2003 & 18.7 & 2008 & 13.0 \\
\hline 5 & 2001 & 37.7 & 1974 & 34.3 & 1995 & 18.3 & 1994 & 13.0 \\
\hline \multicolumn{9}{|c|}{ Campos Sales } \\
\hline 1 & 1963 & 38.4 & 1985 & 32.8 & 1998 & 18.8 & 1982 & 10.8 \\
\hline 2 & 1963 & 38.0 & 1976 & 33.3 & 1998 & 18.6 & 1967 & 11.9 \\
\hline 3 & 1963 & 37.4 & 1978 & 33.4 & 2003 & 18.4 & 1967 & 12.1 \\
\hline 4 & 1999 & 37.2 & 1979 & 33.8 & 1964 & 18.1 & 1967 & 13.1 \\
\hline 5 & 2003 & 37.2 & 1976 & 33.8 & 1964 & 18.0 & 1975 & 13.5 \\
\hline \multicolumn{9}{|l|}{ Cratéus } \\
\hline 1 & 2005 & 39.8 & 1970 & 35.2 & 1983 & 21,3 & 1995 & 13.5 \\
\hline 2 & 1997 & 39.0 & 1974 & 35.3 & 1998 & 21.1 & 1974 & 13.8 \\
\hline 3 & 1997 & 38.5 & 1963 & 35.7 & 1998 & 20.6 & 1967 & 14.8 \\
\hline 4 & 1999 & 38.3 & 1976 & 35.9 & 2007 & 20.5 & 1967 & 14.9 \\
\hline 5 & 2006 & 38.2 & 1967 & 35.9 & 1983 & 20.2 & 1975 & 15.3 \\
\hline \multicolumn{9}{|c|}{ Guaramiranga } \\
\hline 1 & 1963 & 31.2 & 1974 & 26.3 & 1998 & 17.4 & 1973 & 10.0 \\
\hline 2 & 1963 & 31.0 & 1974 & 26.4 & 2006 & 17.3 & 1974 & 10.9 \\
\hline 3 & 1993 & 31.0 & 1978 & 26.4 & 1998 & 17.2 & 1973 & 12.2 \\
\hline 4 & 1968 & 30.6 & 1975 & 26.6 & 2006 & 17.1 & 1994 & 12.4 \\
\hline 5 & 1969 & 30.5 & 1976 & 26.8 & 2006 & 17.1 & 1970 & 13.0 \\
\hline \multicolumn{9}{|l|}{ Jaguaruana } \\
\hline 1 & 1993 & 37.6 & 1969 & 34.7 & 1998 & 21.9 & 1974 & 10.9 \\
\hline 2 & 2002 & 37.6 & 1974 & 34.8 & 2004 & 20.8 & 1962 & 11.2 \\
\hline 3 & 1979 & 37.5 & 1974 & 34.9 & 2006 & 20.8 & 1973 & 12.2 \\
\hline
\end{tabular}


Continuação Tabela 3

\begin{tabular}{|c|c|c|c|c|c|c|c|c|}
\hline 4 & 1997 & 37.5 & 1974 & 34.9 & 1995 & 20.7 & 1970 & 13.0 \\
\hline 5 & 2003 & 37.4 & 1976 & 35.1 & 1983 & 20.5 & 1968 & 13.2 \\
\hline \multicolumn{9}{|l|}{ Quixeramobim } \\
\hline 1 & 1998 & 39.6 & 1969 & 35.3 & 1998 & 22.8 & 1977 & 13.7 \\
\hline 2 & 2003 & 38.1 & 1963 & 35.3 & 1983 & 22.0 & 1961 & 16.2 \\
\hline 3 & 2006 & 38.1 & 1974 & 35.3 & 1983 & 21.5 & 1974 & 16.6 \\
\hline 4 & 1961 & 37.9 & 1978 & 35.4 & 1998 & 21.5 & 1965 & 16.8 \\
\hline 5 & 2001 & 37.8 & 1971 & 35.4 & 2004 & 21.5 & 1975 & 17.0 \\
\hline Occurrence after 1990 & $73 \%$ & & & & $78 \%$ & & & \\
\hline Occurrence after 2000 & $50 \%$ & & & & $40 \%$ & & & \\
\hline Occurrence before 1980 & & & $85 \%$ & & & & $65 \%$ & \\
\hline
\end{tabular}

area, resulting in a decrease of the quantity of energy used as latent heat of evapotranspiration.

Similar tendencies have been observed in different parts of the globe (BONSAL et al., 2001; LINKOSALO et al., 2009; PITMAN; PERKINS, 2009). This change in the land use is pointed out by the document "Climate Change 2007: The Physical Science Basis" (IPCC, 2007) as the main reason for the increase in air temperature. As for the minimum air temperatures, approximately $78 \%$ of the values greater than the $95^{\text {th }}$ percentile occurred in the last two decades, and around $38 \%$ of these were registered in the period of 2000-2008 (TAB. 3).

The investigation also showed that $65 \%$ of the minimum temperatures less than the value equivalent to the $5^{\text {th }}$ percentile occurred in the 1960s and 70s. Because the minimum air temperatures occur due to the energy in transit from surface of the earth to the atmosphere in the form of sensible heat, the results point toward a reduction in these exchanges, consequently increasing the number of "hot" nights. Such a fact supports the notion that records of extreme air temperatures were initially for the minimums. The increase in the minimum temperatures on both global (BALLESTER et al., 2010; VOSE et al., 2005) and regional (BROHAN et al., 2006; PRIETO et al., 2004) scales has already been detected by several researchers.

\section{Conclusions}

1. The highest values for the maximum and minimum air temperatures for the studied area have been registered in the last 12 years. For the studied period, independent of the regional variations in temperatures, eight stations presented a common tendency in relation to annual rates of increase in the extreme temperatures. In other words, the stations revealed an annual rate of increase in the minimum temperatures that is superior to that of the maximums, representing a higher retention of heat during the night;

2 . The highest rates of increase per century were registered for the minimum temperatures, for the stations of Guaramiranga and Crateús.

\section{Acknowledgements}

The authors would like to acknowledge the Instituto Nacional de Meteorologia (INMET) and the Universidade Federal do Ceará (UFC) for the concession of data, without which it would not have been possible to conduct the study presented here.

\section{References}

BALLESTER, J.; RODÓ, X.; GIORGI, F. Future changes in Central Europe heat waves expected to mostly follow summer mean warming. Climate Dynamics, 2009. <http://www. springerlink.com/content/50p7657r14056011/ p=709e198eefe 24bc596a7ecffc41f2680\&pi=27>. Accessed: 10 may 2010.

BONSAL, B. R. et al. Characteristics of daily and extreme temperatures over Canada. Journal of Climate, v. 14, n. 09, p. 1959-1976, 2001.

BROHAN, P. et al. Uncertainty estimates in regional and global observed temperature changes: a new data set from 1850 . Journal of Geophysical Research, v. 111, p. 1-3, 2006.

FERRON, F. A.; SIMÕES, J. C.; AQUINO, F. E. Série temporal de temperatura atmosférica para a Ilha Rei George, Antártica. Revista do Departamento de Geografia, v. 14, p 25-32, 2001.

HERTIG, E.; JACOBEIT, J. Downscaling future climate change: Temperature scenarios for the Mediterranean area. Global and Planetary Change, v. 63, n. 02/03, p. 127-131, 2008. 
HOMAR, V. et al. Recent trends in temperature and precipitation over the Balearic Islands (Spain). Climatic Change, v. 98, n. 01/02, p. 199-211, 2010.

INTERGOVENMENTAL PANEL ON CLIMATE CHANGE (IPCC). Summary for Policymakers. In: SOLOMON, S. et al. Climate Change: the Physical Science Basis. Contribution of Working Group I to the Fourth Assessment Report of the Intergovernmental Panel on Climate Change. Cambridge: Cambridge University Press; New York: United Kingdom, 2007.

JUNG, H. S. et al. Recent trends in temperature and precipitation over South Korea. International Journal Climatology, v. 22, n. 11, p. 1327-1337, 2002.

KOLOKOTRONI, M, GIRIDHARAN, R. Urban heat island intensity in London: An investigation of the impact of physical characteristics on changes in outdoor air temperature during summer. Solar Energy, v. 82, n. 11, p. 986-998, 2008.

LADOCHY, S.; MEDINA, R.; PATZERT, W. Recent California climate variability: Spatial and temporal patterns in temperature trends. Climate Resource, v. 33, n. 02, p. 159-169, 2007.

LEBASSI, B. et al. Observed 1970-2005 Cooling of Summer Daytime Temperatures in Coastal California. Journal of Climate, v. 22, n. 13, p. 3558-3573, 2009.

LINKOSALO, T. et al. The time series of flowering and leaf bud burst of boreal trees (1846-2005) support the direct temperature observations of climatic warming. Agricultural and Forest Meteorology, v. 149, n. 03/04, p. 453-461, 2009.

LOBELL, D. B.; BONFILS, C. The effect of irrigation on regional temperatures: A spatial and temporal analysis of trends in California, 1934-2002. Journal Climate, v. 21, n. 10, p. 2063-2071, 2008.

LOPES, J. F. B. et al. Tendência de mudanças da temperatura em Fortaleza, Ceará. In: WORKSHOP INTERNACIONAL DE INOVAÇÕES TECNOLÓGICAS NA IRRIGAÇÃO, 2., 2008, Fortaleza. Anais... Fortaleza: UFC, 2008.

MARENGO, J. A. et al. Future change of temperature and precipitation extremes in South America as derived from the
PRECIS regional climate modeling system. International Journal of Climatology, v. 29, p. 2241-2255, 2009.

MARENGO, J. A. Vulnerabilidade, impactos e adaptação à mudança do clima no semi-árido do Brasil. Brasília: Parcerias Estratégicas, 2008.

MARENGO, J. A.; VALVERDE, M. C. Caracterização do clima no Século XX e cenário de mudanças de clima para o Brasil no século XXI usando os modelos do IPCC-AR4. Revista Multiciência, v. 08, p. 5-28. 2007.

PEREIRA, P.; MORAIS, L. Clima urbano e evolução da temperatura estival em Lisboa no século xx. Tendência, número de noites quentes e amplitude térmica diária. Finisterra, v. 42, n. 83, p. 109-126. 2007.

PETERSON, T. C. Assessment of urban versus rural in situ surface temperatures in the contiguous United States: no difference found. Journal of Climate, v. 16, p. 2941-2959, 2003.

PITMAN, A. J.; PERKINS, S. E. Global and Regional Comparison of Daily 2-m and 1000-hPa Maximum and Minimum Temperatures in Three Global Reanalyses. Journal of Climate, v. 22, n. 17, p. 4667-4681, 2009.

PRIETO, L. et al. Minimum extreme temperatures over Peninsular Spain. Global and Planetary Change, v. 44, n. 01/ 04, p. 59-71, 2004.

SILVA, V. P. R. On climate variability in Northeast of Brazil. Journal of Arid Environments, v. 58, n. 04, p. 575-596, 2004.

SPENCER, R. W. The Great Global Warming Blunder: how Mother Nature Fooled the World's Top Climate Scientists. New Yourk: Encounter Books, 2010.

VOSE, R. S.; EASTERLING, D. R.; GLEASON, B. Maximum and minimum temperature trends for the globe: an update through 2004. Geophysics Resource Letter, v. 32, 2005.

WALTERS, J. T. et al. Positive surface temperature feedback in the stable nocturnal boundary layer. Geophysical Resource Letters, v. 34, 2007. 